\title{
ÖRGÜTSEL DAVRANIŞTA GÖNÜLLÜK EKSENINDE GELIŞEN, BİRBIRINII TAMAMLAYICI PARADİGMALAR: KURUMSAL VATANDAŞLIK (ÖRGÜTSEL VATANDAŞLIKTAN FARKLI MI? KURUMSAL SOSYAL SORUMLUĞA NE KADAR YAKIN?)
}

\author{
İsmail BAKAN \\ Prof. Dr., KSÜ, İIBF, İșletme Bölümü, \\ ORCID: 0000-0001-8644-8778 \\ Y. Sonay YILMAZ \\ Doktora Öğrencisi, KSÜ, İ̈BF, İșletme Bölümü, \\ ORCID: 0000-0003-1659-7799
}

\begin{abstract}
Öz
Örgütsel vatandaşlık, kurumsal vatandaşlık ve kurumsal sosyal sorumluluk güncel yönetim konuları içerisindeki önemli kavramlardır. Yönetim konuları içerisinde yer alan bu kavramlar, günümüzdeki anlamlarına ulaşırken birçok aşamadan geçmiş ve bazı alanlarda kavramsal olarak birbiriyle örtüşmüştür. Araştırmadaki bu üç kavram sosyal bir bakış açısı ile incelenmeye çalıșılmıștır. Örgütsel vatandaşlık, bireylerin kurumuna ve beraber çalıştığı kișilere karşı olumlu davranışları içeren faaliyetler olup hedefi kurum ve beraber çalıștığı kişilerdir. Bir kurum tarafından içinde bulunduğu topluma karşı gönüllülük esaslı davranışları ifade eden ve işletmelerin ana unsur olduğu kurumsal vatandaşlığın hedefi faaliyetlerini yürüttügü toplumdur. Kurumsal sosyal sorumluluk ise işletmelerin çevrenin tüm değerlerini dikkate alarak paydaşlarına zarar vermeden yerine getirmesi gereken yükümlülüklerini ve yapmak zorunda olduğu davranışları ifade etmektedir. Literatür bulgularında, örgütsel vatandaşlık ile kurumsal vatandaşlık birbirinden farklı davranışları ifade eden kavramlarken; kurumsal vatandaşlık ve kurumsal sosyal sorumluluğun anlam bakımından birbirine yakın davranışları ifade ettiği ve birbirinin ikamesi değil tamamlayıcısı olduğu görülmektedir. Kurumsal vatandaşlık ve kurumsal sosyal sorumluluk arasındaki ilişki oldukça belirsiz olup, bazı bilim insanları temel unsurlarındaki farklılıkları vurgulamakla birlikte, genelde benzer yaklaşımlar olduklarını ifade etmektedirler. Anahtar Kelimeler: Kurumsal Vatandaşlık, Örgütsel Vatandaşlık, Kurumsal Sosyal Sorumluluk.
\end{abstract}

\section{COMPLEMENTARY PARADIGMS DEVELOPED IN ORGANIZATIONAL BEHAVIOR ON THE AXIS OF VOLUNTARY: CORPORATE CITIZENSHIP (DIFFERENT FROM ORGANIZATIONAL CITIZENSHIP? HOW CLOSE TO CORPORATE SOCIAL RESPONSIBILITY?)}

\footnotetext{
Abstract

Organizational citizenship, corporate citizenship and corporate social responsibility are important concepts in current management issues. These
} 
concepts, which are included in management issues, have gone through many stages while reaching their current meanings and overlapped with each other conceptually in some areas. These three concepts in the research were tried to be examined from a social point of view. Organizational citizenship is activities that include positive behaviors towards the institution of individuals and the people they work with, and its target is the institution and the people they work with. The target of corporate citizenship, which expresses the voluntary-based behavior of an institution towards the society in which it is located, and in which the enterprises are the main element, is the society in which it carries out its activities. Corporate social responsibility, on the other hand, refers to the obligations and behaviors that businesses must fulfill without harming their stakeholders, taking into account all the values of the environment. In the literature findings, while organizational citizenship and corporate citizenship are concepts that express different behaviors; it is seen that corporate citizenship and corporate social responsibility express behaviors that are close to each other in terms of meaning and that they are complementary rather than substitutes for each other. The relationship between corporate citizenship and corporate social responsibility is rather vague, with some scholars emphasizing the differences in their basic elements but generally stating that they are similar approaches.

Keywords: Corporate Citizenship, Organizational Citizenship, Corporate Social Responsibility.

\section{GİRIS}

Çağdaş yönetim anlayışı içerisinde çalışanlar ve işletme arasındaki ilişkileri konu alan yeni kavram ve uygulamalar ortaya çıkmaktadır. Bu kavramlar bazen birbirleriyle yakın ilişki içinde olmakta ve bazen de aynı konuyu farklı yönleri ile ifade etmektedir (Koçel, 2015: 530). Organizasyonlarda birçok davranış türleri akademik çalışmalara araştırma konusu olmuştur. Bu çalışmalara, örgütsel adalet, örgütsel vatandaşlık, kurumsal vatandaşlık, örgütsel adanmışlık, örgütsel sinizm, örgütsel sessizlik, örgütsel kayıtsızlık vb. gibi konular örnek olarak verilebilir. Davranış türlerinin bu şekilde çok detaylı bir şekilde incelenmesi kurumların gelişmesine, rekabet güçlerinin artmasına, piyasa koşullarında ayakta kalmalarına ve etkin bir yapıya kavuşmalarına büyük katkı sağlamaktadır. Davranış türleri üzerinde yapılan çalışmalardan hedeflenen bilimsel faydayı sağlamak için söz konusu davranış türlerinin sınırlarının iyi belirlenmesi ve tanımlanması gerekmektedir. Çünkü bilimsel araştırmalarda davranıș türlerinin birbirinin yerine kullanılması, benzer anlamlara gelecek ifadelere yer verilmesi bazen kavram karmaşılılığına yol açabilmektedir. Terminolojik olarak birbirine benzerliği çok yakın olan örgütsel vatandaşlık, kurumsal vatandaşlık ve kurumsal sosyal sorumluk arasında bu karmaşıklığın olma ihtimali yüksektir.

Örgütsel vatandaşlık Koçel (2015: 530) tarafından; organizasyonlarda görev yapan kişilerin, asli görev tanımında olmayan ve yapmaması halinde herhangi bir yaptırımla karşılama durumunun olmamasına karşın, kendince sorumluluk duymasına bağlı olarak kurumda alınan kararlara destek çıkma, yardımlaşma, kurum uygulamalarını kurum dışında da savunma, işletmede ortaya çıkan bir sorunu çözmek için uğraşma gibi davranışları içeren gönüllülük esası odaklı davranış gösterme șekli olarak ifade edilmektedir. Kurumsal vatandaşlık ise kurumların varlıklarını sadece ekonomik amaçları üzerinden yürütemeyeceği, aynı zamanda kamu sektörü, diğer özel sektör ve sivil toplum kuruluşlarıyla işbirliği 
halinde refah artışının yaygınlaştırılması ve sürdürülebilir kılınması gibi konularda bir ülkenin vatandaşı gibi sorumluluklar üstlenmesi gerektiği anlayışını ön planda tutan davranışlardır (Ateş vd., 2019: 115). Başka bir ifade ile işletmeleri ayrı tüzel kişilikler olarak ülkelerin üyeleri olarak gören, bir kuruluşun toplum üzerindeki etkileri ve toplumla olan ilişkilerinde olumsuzu en aza indirerek, olumlu olanı en üst düzeye çıkaracak şekilde anlama ve yönetme şekli olarak tanımlanmaktadır (Marsden ve Andriof, 1998: 329). Örgütsel vatandaşlk, işletmelerde görev yapan bireylerin organizasyonlarda iyi birer vatandaş olarak davranma çabalarına odaklanırken, kurumsal vatandaşlık işletmelerin toplumda sorumlu bir şekilde hareket etmesi için üstlendiği girişimleri belirler. Örgütsel vatandaşlık ve kurumsal vatandaşlık birbirinden bağımsız olarak gelişmiştir (Swaen ve Maignan, 2001: 3). Organizasyonların hedeflerine ulaşmak için hizmet sunduğu toplum ile iyi ilişkiler kurma odaklı olan kurumsal sosyal sorumluluk, kurumların topluma karşı sorumluluklarını yerine getirirken, toplumun iş dünyasından beklentileri ile iş etiği arasındaki uyum derecesi olarak tanımlanmaktadır. Kısaca toplumsal beklentiler ile firma yöneticilerinin meșru toplumsal talepler olarak gördükleri arasındaki uyumdur (Zenisek, 1979: 362).

Örgütsel vatandaşlı, kurumsal vatandaşlık ve kurumsal sosyal sorumluluk gibi davranışlar onlarca yıldır örgütsel davranış disiplininin önemli konuları olmuştur. Kavramların ifade ettiği anlamın zaman zaman birbiriyle örtüştüğü ve bazen birbirinin tamamlayıcısı olduğu, örgütsel vatandaşlık, kurumsal vatandaşlık ve kurumsal sosyal sorumluk davranışlarının üçünün birlikte incelendiği çalışmalara rastlanılmamıştır. Bu davranışların ayrı ayrı konu alındığı araștırmalar incelenerek aralarındaki farklılık ve benzerliklerin incelenmesi bu davranışların daha iyi anlaşılmasına yardımcı olacaktır. Bu kapsamda yapılan bu literatür araştırmasında öncelikle örgütsel vatandaşlık, kurumsal vatandaşlık ve kurumsal sosyal sorumluğa özgü davranışları ve bu kavramlar üzerine yapılan çalışmaları ele almak hedeflenmiştir. Ayrıca bu davranış türlerinin neleri kapsadığı, neleri kapsamadığı, hangi alanlarda benzerlik ve farklılıklar gösterdikleri karşılaştırılarak, bu kavramlar arasındaki ilişkiler açıklanmaya çalışılmıştır.

\section{2. ÖRGÜTSEL VATANDAŞLIK}

Organizasyonların etkinliğinde, maddi kaynak yapılarından önce sahip oldukları insan kaynaklarının kalitesi büyük bir öneme sahiptir. Çalışanların öngörülen görevlerinin dışında, kendi istekleri ile örgütün faaliyet ve etkinliğine katkıda bulunmaları, diğer çalışanlara yardımcı olmaları, üstlendikleri görevden fazlasını yapmak için çaba sarf etmeleri önemli bir davranış şeklidir (Sezgin, 2005: 334). Organizasyonlarda birçok faaliyetin insan kaynağıyla gerçekleștirildiği göz önünde tutulduğunda, çalışanların farklı konulardaki algıları ve davranışları son derece önemlidir. Organizasyonlardaki bireyler örgüt içindeki uygulama ve faaliyetlere karşı çeşitli tutum ve davranışlar sergilemektedir. Bu amaçla örgütte uygun ortamın yaratılması, iş görenlerin rol tanımlamasının ötesinde gönüllü olarak, herhangi bir beklenti içerisinde olmaksızın davranışlar sergilemesini teşvik etmektedir (Poyraz vd., 2009: 72).

Geleneksel iş performansı ölçütleri ile belirlenemeyen, ancak uzun süreli örgütsel başarı için umut vaat eden birçok terim kullanılmaktadır. Bu kavramların ortak teması, uzun vadede örgütsel etkinliğe katkıda bulunmanın yanı sıra iş davranıșlarını da belirlemesidir (Dyne vd., 1994: 765). Toplumların gelişiminde 
önemli etkisi olan örgütler, günlük yaşamda önemli bir role sahiptir. Globalleşme ve artan rekabet koşulları organizasyonları yeni arayışlara yönlendirdiğinden, bu durum örgüt çalışanlarına yeni görev ve sorumluluklar yüklemektedir. İş hayatında formel görevlerin üzerinde tutum ve davranışların ön plana çıkması, örgütleri çalışanlara daha bağımlı hale getirmektedir. Örgüt faaliyetlerinin etkinliği ve verimliliğinde önem kazanan, çalışanların bir karş̧lık beklemeksizin gönüllü olarak arkadaşlarına ve kurumuna karşı olumlu tutum ve davranışlar sergilemesi olarak ifade edilen örgütsel vatandaşlık davranışları, üzerinde durulan önemli bir konu haline gelmiştir (Sökmen ve Boylu, 2011: 147).

Çalışanların ekstra rol davranışını, yani gönüllü olan ve normal rol beklentilerinin ötesine geçen davranışını ifade eden örgütsel vatandaşlık, 1980'li yıllardan bu yana iş yaşamında önemli bir araştırma konusu olmuștur (Allison vd., 2001: 282). Organizasyon tarafindan resmi olarak ödüllendirilmeyen veya cezalandırılmayan isteğe bağlı, ekstra rol davranışı olarak tanımlanan örgütsel vatandaşlık, verimliliği ve etkinliği artırarak organizasyona fayda sağlar (Schnake ve Dumler, 2003: 284). Siradan kullanımda vatandaşlık, bir yere ait olma durumunu tanımlar ve hem hakları hem de sorumlulukları ifade eder. Graham tarafından örgütsel vatandaşlık davranışı; kuralların ve düzenlemelerin rasyonel yapısının gerekliliğini tanıyan ve kabul eden itaat, organizasyonla özdeşleșme, örgütü tehditlere karşı savunma ve çıkarlarına hizmet etmek olan bağlllık ve örgütsel işlere ilgi, örgütsel yönetişime karşs sorumlu olma ve yeni fikirleri paylaşma olan katılım olmak üzere üç kategoride değerlendirilmektedir. Graham, örgütsel vatandaşlık davranışlarının faydalanıcısının sadece örgüt olmadığını, organizasyon üyelerinin örgütsel olarak ilgili tüm davranışlarını ve örgütün hedeflerini de içeren küresel bir kavram olduğunu belirtmiş ve örgütsel olarak ekstra rol ve rol içi davranışları içerdiğini ifade etmiştir (Graham, 1991: 251). Graham'ın örgütsel vatandaşlık kavramına ilişkin bu yaklaşımının, Organ (1990: 43), Brighman ve Moran (1999: 684) ve Altıntaş (2006: 89) gibi örgütsel vatandaşlığın gönüllülük esasına dayandığını ifade eden araştırmacılardan farklı olduğu görülmektedir.

Graham'ın örgütsel vatandaşlık davranışı yaklaşımı Podsakoff vd. (1990: 115) tarafından biraz daha farklı şekilde ifade edilmiştir. Podsakoff vd.'ne göre örgütsel vatandaşlık, fedakârlık (özgecilik), vicdanlılık, nezaket tabanlı bilgilendirme, sivil erdem ve centilmenlik gibi davranış boyutlarından oluşmaktadır. Fedakârlık; bireylerin kendi istekleri ile iş yükü ağır olan veya yapmakta güçlük yaşayan diğer kişilere yardım ederek onların performanslarını arttırmak için yardımcı olma davranışıdır. Bu davranış, örgüt içerisindeki gerginlik ve çatışmaların azalmasına katkı sağlamaktadır. Vicdanlılık; bireylerin herhangi bir şikâyette bulunmadan ideal koşullardan daha azını kabul etme halidir. Buna örnek olarak kötü hava koşullarında dahi işe gitme isteği, yemek ve kahve aralarını uzatmamak gibi davranışlar verilebilir. Yani örgütün faydası için özverili davranış sergilemektir. Nezaket tabanlı bilgilendirme; beraber çalıştığı kişilerin işle ilgili sorunlarını ortaya çıkmasını önlemeyi amaçlayan, onları korumaya yönelik eylemlerdir. Yani herhangi bir davranıșta bulunmadan önce bilgi vermedir. Sivil erdem; organizasyonun kararlarına katılarak örgütün gelişimi konusunda kendini sorumlu görmek, alınan kararlarda söz sahibi olmak, görüş ifade etmektir. Centilmenlik; işletmede çalışanlar arasında ve çalışanlar ile yöneticiler arasındaki oluşabilecek olumsuz davranışlardan kaçınmak için gösterilen çaba ve gayretlere 
yönelik davranışlardır. Yine Podsakoff vd. (2000: 516) örgütsel vatandaşlık davranışlarını tekrar düzenleyerek; yardımcı davranış, sportmenlik, örgütsel sadakat, örgütsel uyum, bireysel girișim, sivil erdem ve kișisel gelișim olmak üzere yedi başlık altında gruplandırmışıtır. Her ne kadar Podsakoff vd. (2000: 516) tarafından örgütsel vatandaşllk yedi boyut olarak değerlendirilse de akademik çevrelerce beş boyutun esas alındığı çalışmalar daha yaygın olarak görülmektedir.

Örgütsel vatandaşlık davranıșı üzerine birçok araștırma yapılmasına karşın kesin tanımı veya operasyonel hale getirilmesi konusundaki tartışmalar devam etmektedir. Bunun nedeni kısmen örgütsel vatandaşlık davranışı üzerine yapılan araştırmaların çoğunun yapının doğasını tanımlamak yerine, diğer yapılar arasındaki ilişkileri anlamaya odaklanmış olmasıdır. Bununla birlikte ayırt edici bir özellik, yöneticilerin astlarından örgütsel vatandaşlık davranışlarını gerçekleştirmesini talep edemeyecek veya zorlayamayacak olmasıdır. Ayrıca çalışanların bu isteğe bağlı davranışlar için herhangi bir resmi ödül beklemiyor olmasıdır. Hâlbuki denetçiler, astlar tarafından sergilenen bu davranışları hem doğrudan hem de dolaylı bir şekilde düzenli olarak dikkate alır ve ödüllendirirler. $\mathrm{Bu}$ davranışların önemli bir özelliği bireyleri genellikle içsel olarak motive etmesidir. Yani bireyin başarı duygusu, yeterlilik, aidiyet veya aidiyet duygusuna olan içsel ihtiyacından kaynaklanmasıdır (Jahangir, 2004: 77).

Örgütsel vatandaşlık davranışlarının örgütlere göre farklı sonuçları olabileceğinden bunların ayrı ayrı değerlendirmesi daha uygun olabilir. Örneğin, başkalarına karşı çok yardımcı ve işbirlikçi (yüksek fedakarlık) eğilim gösteren ancak aynı zamanda örgütü etkileyen kararlara dahil olma konusunda tereddütlü (düşük yurttaşlık erdemi) olan birini hayal etmek zor değildir. Buradaki ilk davranışın, üyelerin küçük gruplar veya ekipler halinde çalıştğı kuruluşlar için daha önemli olması muhtemelken, ikincisi üyelerin aktif katılımında rekabetçi tehditlerin kritik olduğu organizasyonlar için daha önemli olabilir (Lepine, 2002: 62). Her kuruluşun başarısı çalışanlarının katılımı ve iyi davranışları üzerine inşa edildiğinden, liderlerin yönetim zorluklarının üstesinden gelmesi ve kuruluşun hedeflerine ulaşması, gönüllülük duygusu üzerine kurulan örgütsel vatandaşlık kültürünün yaratılmasına bağlı olmaktadır. Örgütsel vatandaşlığın geliştirilmesi eğitim ve işten ayrılma maliyetlerini azaltabilir, kalite, performans ve müşteri memnuniyetini ise artırabilir. Uyumlu çalışma ekipleri günlük işlere yüksek değerler katar. Etkili bir vatandaşlık modelini desteklemek, geniş tabanlı yapısal değişim yaratmaya ve etkili müdahale programlarının oluşturulmasına katkı sağlar. Örgütsel vatandaşlığın gelişmesi, yönetimin meşguliyetini azaltır. İyi bir yönetim ve geniş tabanlı bağllılı sayesinde, çalışanların yeteneklerinden en iyi şekilde faydalanılır (Brighman ve Moran, 1999: 684).

İşletmelerde örgütsel vatandaşlık davranışlarının benimsenmesi için çalışanları teşvik eden, katılımcı ve karşılıklı etkileşime dayalı bilgi alışverişinin olduğu bir örgüt iklimi oluşturulmalıdır (Sezgin, 2005: 334). Türkiye'de yapılan araştırmalarda, bireylerin örgütleri için göstermiş olduğu fedakârlı temelini esas alan örgütsel vatandaşlık davranışı; bireylerin beraber çalıştı̆̆ı kişilere yardımı, kurumuna karşı olumlu çabaları, işine olan özeni ve alınan kararlara katılımının düzeyleri üzerine kurulmuştur (Bolat vd., 2009: 238). Yapılan araştırma sonucunda bilim insanlarının örgütsel vatandaşlık konusundaki görüşleri özetlenerek Tablo 1' de verilmeye çalışılmıştır. 
Tablo 1. Örgütsel Vatandașlık ile İlgili Bilim İnsanlarının Görüșleri Graham (1991: 251), örgütsel vatandaşlık davranışlarının faydalanıcısının sadece örgüt olmadığını, örgütsel olarak ilgili tüm davranışları ve örgütün hedeflerini de içeren küresel bir kavram olduğunu ve örgütsel olarak ekstra rol ve rol içi davranışları içerdiğini ifade etmiştir.

Schnake ve Dumler (2003: 284)'a göre, organizasyon tarafından resmi olarak ödüllendirilmeyen veya cezalandırılmayan isteğe bağlı, ekstra rol davranıșı olarak tanımlanan örgütsel vatandaşlık, verimliliği ve etkinliği artırarak organizasyona fayda sağlamaktadır.

Organ (1990: 43)'a göre, örgütsel vatandaşlık gönüllülük esasına dayanmaktadır.

Jahangir (2004: 77), yöneticilerin; astlarından örgütsel vatandaşlık davranışlarını gerçekleştirmesini talep etmemesine veya zorlamamasına karşın, astlar tarafından sergilenen bu davranışları hem doğrudan hem de dolaylı bir șekilde dikkate alıp düzenli olarak ödüllendirdiğini belirtmiștir.

Lepine (2002: 62), örgütsel vatandașlık davranıșlarının örgütlere göre farklı sonuçları olabileceğinden bunların ayrı ayrı değerlendirilmesinin daha uygun olacağını ifade etmiștir.

Podsakoff vd. (2000: 516)'ne göre, örgütsel vatandaşlık; fedakârlık (özgecilik), vicdanlılık, nezaket tabanlı bilgilendirme, sivil erdem ve centilmenlik davranıșlarını içermektedir.

Swaen ve Maignan, (2001: 10)'a göre, örgütsel vatandaşlık davranışlarının öncüleri olarak iş memnuniyeti, örgütsel bağlllık, algılanan adalet, lider desteği ve yönetime güven duygularına yansımalarının olacağı, bunların sonucunda da performans, çalışma kalitesi devir hızı, işbirliği, organizasyon verimliliği ve müşteri servis hizmetleri etkilenecektir.

Brighman ve Moran (1999: 684)'a göre, çalışanların katılımı ve iyi davranışları üzerine inşa edilen ve gönüllülük duygusu üzerine kurulan örgütsel vatandaşlık; örgütün eğitim ve işten ayrılma maliyetlerini azaltabilir, kalite, performans ve müşteri memnuniyetini arttırabilir ve çalışanların yeteneklerinden en iyi şekilde fayda sağlamayı mümkün kılar.

\section{KURUMSAL VATANDAŞLIK}

Bir ișletmenin toplum üzerindeki etkilerini ve toplumla olan ilișkilerini yönetmesi olarak tanımlanan kurumsal vatandaşlık kavramını ve sonuçlarını anlamaya çalışmadan önce, işin gerçekleștiği bağlamı anlamak gerekir. İşletmeler, gerçekte faaliyet gösterdikleri bölgelerin vatandaşları olarak hakları ve görevleri olan tüzel kişilikler olarak kabul edilir. Bu haklar ve görevler, geleneksel olarak belirli asgari yasal gerekliliklere ve yasama alanına göre ulusal veya bölgesel birliğe göre değișen sosyal alanları olan ek davranış normlarına tabidir. Kurumsal vatandaşlık, temel olarak bir işi iyi yürütmek, yasalara uymak, vergileri ödemek ve diğer sorumlu vatandaşlar gibi iyi bir davranış sergilemeyi öngörür (Marsden, 2000: 11).

Bir organizasyonun temel işletme faaliyetleri, sosyal yatırımları, gönüllü programları ve kamu politikasındaki yükümlülüğüyle topluma yaptı̆̆ katkılar kurumsal vatandașlık olarak ifade edilir. Örgütlerin kurumsal vatandașlığı çalıșanlar, müșteriler, ișletme ortakları, hükümetler ve topluluklar gibi farklı paydaşların yanı sıra ekonomik, sosyal ve çevresel ilişkileri yönetmedeki tarzı ile 
belirlenmektedir. Diğer bir ifade ile kurumsal vatandaşlı örgütlerin, toplumun üyeleri olarak görevlerini yerine getirmek için üstlendikleri sosyo-ekonomik aktiviteleri ifade etmektedir. Kurumsal vatandaşlık, temel bir işletme ilkesi olarak örgütlerin toplum üzerindeki etkilerini daha fazla dikkate alan yeni ekonomik sistemi anlamada bütünleyici bir role sahiptir (Gardberg ve Fombrun, 2006: 329).

Yönetim literatüründe kurumların sosyal sorumluluklarını ifade eden kurumsal vatandaşlık, işletmelerin faaliyetlerini sürdürürken belirlenen yasal, etik ve sosyal kurallara uyması ve toplumun beklentilerini karşılamasıdır. Toplum içinde yaşayan bir kişinin nasıl ki vatandaşlıktan kaynaklanan sorumlulukları var ise işletmelerin de paydaşlarına karşı sorumlulukları vardır. Organizasyonların paydaşları ile etkin bir vizyon ve misyon paylaşımı sağlaması kurumsal vatandaşlı̆̆ geliştirir (Akatan, 2007: 15).

İşletmelerin sosyal rolüyle ilgili yönetim uygulamalarında öne çıkan bir terim olarak kurumsal vatandaşlı ile ilgili (Matten ve Crane, 2005: 166) ilk yayınların 1969'a kadar gittiği ve araştırmaların 2004 yılında ivme kazandığı ve o zamandan bu yana değişken sayıda yıllık yayınların olduğu görülmektedir. 2007 yllında hızla büyümeye başlayan atıflar, 2014' ten bu yana bir platoya ulaşmıştır. 0 zamandan beri küresel iş dünyasının uygulamalarına girmeye başlayan kurumsal vatandaşlığın mevcut durgunluk aşamasından çıkıp çıkmayacağı ve yeniden hızlanıp hızlanmayacağı ise belirsizdir (Kruggel vd., 2020: 15). Son yıllarda kullanımı artan bir terim olan kurumsal vatandaşlık kavramı hakkında yapılan çalışmalar göz önüne alındığında, aslında bu alanda çalışan dünyadaki bilim insanlarının bu kavramı uzun süredir kullandıkları görülmektedir.

Organizasyonların, yerel topluluk düzeyinden başlayarak ortak sorunları çözmeye ve kurumsal operasyonların olumsuz etkilerini en aza indirmeye yönelik çözümleri ve yaklaşımları, 2000'li yıllarda kurumsal vatandaşlı̆̆ın bir parçası olarak kabul edilmektedir. Kurumsal vatandaşlık günümüzde; proaktif katılım, global kurumsal vatandaşlık, paydaş iliş̧ileri, dönüşüm, iş fırsatı ve toplumsal ortaklık olmak üzere altı kategoride değerlendirilmektedir (Altman ve Cohen, 2000: 1). Bireylerin tüketime yönlendirildiği, işletmelerin daha fazla üretmeyi ön planda tuttuğu günümüzde işletmelere önemli sorumluluklar düşmektedir. Bu sorumluluklar kapsamında kurumsal vatandaşlıkta üç ana tema ön plana çıkmaktadır. Birincisi, işletmeler hukuka, ahlak standartlarına, çevreye ve insan haklarına tam anlamıyla uyumlu ve saygllı davranmalıdır. İkincisi, işletme faaliyetlerini sadece kendisi için değil aynı zamanda içinde bulunduğu tüm sosyal paydaşları ile işbirliği içinde yürütmelidir. Son olarak ise bütün bunların yürütülmesinde işletmenin yönetim kurulu ve başkanlarının sorumlu olduğu kabul edilmelidir (Sarıkaya ve Kara: 2007: 229).

Kurumsal vatandaşlığın iş başarısının büyüyen bir yönü olduğu konusundaki (Waddock, 2001: 25; Lin, 2010: 528; Bulduklu, 2014: 1) birçok araştırma göz önüne alındığında, işletmelerin kurumsal vatandaşlığı daha önemsemesi gerektiği ve bu tür faaliyetlerin markalaşma için öneminin giderek arttığı iddia edilmektedir. Kurumsal vatandaşlık aynı zamanda markalaşma mekanizması yoluyla ticari başarıyı besler. Tüketici araştırmaları insanların işletmeleri, değerleri, toplumdaki rolleri ve davranışları konusunda giderek daha fazla yargıladıklarını göstermektedir. Bazen işletimlerin reklamı olarak görülen 
kurumsal vatandaşlı̆ı̆ın işletmeye olan güveni artırmaya yardımcı olduğuna dair önemli kanıtlar vardır. Bu daha yüksek memnuniyetle ilgili olup, daha fazla müșteriyi elde tutarak daha büyük ticari başarıyı beraberinde getirir (Willmott, 2003: 362).

Kurumsal vatandaşlığı anlamlandırma söz konusu olduğunda, çoğu şey bir işletmenin bugüne kadar neler başardığına ve ne kadar ileri gitmek istediğine bağlıdır. İş dünyasında bilgileri, tutumları, yapıları ve uygulamaları ile kurumsal vatandaşlık hakkında farklı anlayış ve karmaşıklık derecelerini temsil eden geniş bir örgüt yelpazesi vardır. Bir işletmenin hangi aşamada olduğunu ve vatandaşlğ̆ ilerletmede hangi zorluklarla karşslaştığını bilmek, bir yöneticinin işlerin ne aşamada olduğu hakkındaki kafa karışıklığını giderebilir, nereye gideceğine ilişkin stratejik seçimleri belirler ve belki de ileriye doğru hareketi hızlandırabilir (Moon vd., 2005: 429). Organizasyonlar kurumsal vatandaşlığı sadece toplumdaki itibarlarını artırmak için değil, aynı zamanda çalışanlarının işe bağlılığını ve güvenini kazanmak için de yararlı olan bir dizi anlamlı sosyal uygulamalar olarak görmektedir. Kurumsal vatandaşlıktan elde edilen faydalara, ürünü için yüksek fiyat talep etme, iyi bir iş imajı olușturma veya yatırım çekme yeteneği örnek olarak gösterilebilir. Çalışanlar genellikle kurumsal vatandaşlıkla ilgili olarak organizasyonlarına güçlü bir bağlllık hissettiklerinden kurumsal vatandaşlığın çalışanların sevgisine ve motivasyonuna olumlu bir şekilde katkıda bulunduğu söylenebilir (Lin, 2010: 518).

Kurumsal vatandaşlık sergileyen bir kuruluş, paydaşlarının çıkarlarını finansal ve normatif kriterlerle karşılamak için kaynaklarını kullanmaya duyarlı olur. Kurumsal vatandaşlık dört tür sorumluluk gerektirir. Birincisi kar ve işletme verimliliği için sağlam bir strateji, yani hissedarların kar elde etmesini ve çalışanların iş sahibi olmasını sağlayan mali sorumluluk, ikincisi kanunlara ve tüm faaliyet alanlarında düzenlemelere uymak olan yasal sorumluluktur. Üçüncüsü çalışanlara, tedarikçilere ve müşterilere adil davranmak ve karar vermede şeffaflık sergilemek gibi ilkeli beklentilere uymayı gerektiren etik sorumluluk ve sonuncusu ise isteğe bağlı, hayırsever olmayı veya toplum katılımı ve çalışanların iş-aile destek programları aracıllğılyla geri vermeyi içeren sorumluluklardır. Bu dört sorumluluk, genel olarak toplum içindeki paydaşların kuruluşlardan beklentilerinin genişliğini yansitır (Evans ve Davis, 2014: 130).

Yeni ekonominin dinamik karmaşıklığı içinde iyi bir kurumsal vatandaşlık geliştirmek, işletmelerin paydaşlarla ilişkileri geliştirmesi ve sürdürmesi gerektiği anlamına gelir. İşletmelerin kurumsal vatandaşlık uygulamalarında, bütünsel bir vizyon ve nispeten yüksek bilişsel, ahlaki ve duygusal gelişim düzeylerine ulaşmalarını sağlayan farkındalık ilkelerini benimsemesi gerekir. Paydaşlarla ilişkiler olarak tanımlanan kurumsal vatandaşlık için firmalar sadece bütünsel bir vizyona değil, aynı zamanda öznel unsurlara dayalı bir vizyona da sahip olmalıdır. Ayrıca düşünme ve öğrenme yeteneklerini geliştirerek kurumsal vatandaşlık için artan talepleri karşılamalıdır (Waddock, 2001: 25). Kurumsal vatandaşlık davranışları etik standartlara uygun, paydaşların yararına ve genel çevresel taahhütleri içerecek şekilde olmalıdır (Davenport, 2000: 211).

İşletmelerin politik bir rol üstlenerek kurumsal vatandaşlar olarak hareket ettiği ve iş dünyasının toplumdaki değișen rolü için rehber oldukları söylenebilir. 
Kurumsal vatandaşlık, işletmelerin işletme dışı kolektif eylem sorunlarıyla dolu rekabetçi bir piyasa ekonomisinde ahlaki arzuları nasıl gerçekleştirebileceklerine yardımcı olur. Ekonomik oyunun kurallarına katkıda bulunarak, kurumsal rolüne ilişkin bir kazan-kazan görüşü ön planda tutulur. İşletmeler, kurumsal vatandaşlar olarak sosyal ikilem durumlarının üstesinden nasıl gelebilecekleri konusunda önerilere odaklanır. Kurumsal vatandaşlar, ekonomik değer yaratma süreçlerini geliştirecek bir üretim faktörü olarak ahlaki taahhütleri kullanma seçeneğine sahip olmalıdır. Bu nedenle, sağduyulu kurumsal vatandaşlar, sosyal ikilemlerin özelliği olan kar elde etme ve ahlaki davranma arasındaki çatışmanın üstesinden gelmeye katkıda bulunabilir (Pies vd., 2009: 375). Kurumsal vatandaşlık, kurum ve yerel topluluk arasındaki sosyal bağları güçlendirerek, kurumun yerel toplulukların sosyal dokusuna entegre olmasına yardımcı olur (Fombrun vd., 2000: 85).

İşletmeler, faaliyet gösterdikleri ülkelerin ve giderek küreselleșen pazarlarla birlikte dünyanın vatandaşlarıdır. İyi kurumsal vatandaşlık, bir kuruluşun toplum üzerindeki olumsuz etkilerini ve ilişkilerini en aza indirerek, olumlu olanı en üst düzeye çıkaracak şekilde anlamak ve yönetmekle ilgilidir. Bir işletmenin vatandaşlık performansının etkili yönetiminin önemi, hem kendisi hem de bir bütün olarak toplum için artmaktadır. Kurumlar rekabet avantajını sürdürmek ve büyütmek için vatandaşlık performanslarını yönetmeye giderek daha fazla ihtiyaç duyarlar. Sivil toplum kuruluşları büyük çevresel ve sosyal sorunlara çözüm bulmaya çalışırken, işletmeler ile iş birliğini nasıl oluşturacaklarını bilmeleri gerekir. Ayrı tüzel kişilikler olarak ülkelerin üyeleri olan işletmeler, yasal hakları ve görevleri olan kurumsal vatandaşlar olarak düşünülmelidir (Marsden ve Andriof, 1998: 329). Günümüzde kurumsal vatandaşlı̆̆ın bir bütün olarak görülmesi ve yönetilmesi önerilmektedir. Modern iletişimin tüm dünyada gittikçe artan karmaşıklığıyla bunu yapmamak bir işletmeyi, bir alandaki olumlu eylemlerinin başka yerlerdeki kötü davranışlar tarafindan zayıflatılmasına tamamen açık hale getirmektedir. Kurumsal vatandaşlık, bir şirketin toplum üzerindeki etkilerini ve toplumla olan ilişkilerini anlaması ve yönetmesi olarak tanımlanabilir, ya da ekonomistlerin terimleriyle, dışsallıkları ne kadar iyi içselleştirdiğidir. İyi bir kurumsal vatandaş olma kavramı, toplumun tüm sorunlarına çözüm bulmak değil, onları daha iyi anlayarak onları daha güçlü hale getirilebilecek her türlü çözümü sunabilmektir (Marsden ve Andriof, 1998: 331).

Bir kuruluş tarafından oluşturulan kurumsal vatandaşlı̆̆ın, bireylerin vatandaşlık davranışları üzerinde olumlu bir etkiye yol açması çok olasıdır. Her kuruluş için sınırlı olan kaynakların bir kısmı isteğe bağlı bu tür faaliyetlere harcandığında diğer alanlara harcanacak miktarlarda azalmaya neden olabilmektedir. Kurum çalışanlarının bazıları kuruluşun kaynaklarının keyfi olarak kullanıldığı düşüncesine kapılarak kurumun bu davranışından memnun olmama hissine kapılabilirler. İyi bir kurumsal vatandaşlık için kuruluşların yasal, etik ve takdire dayalı davranışlar arasında denge kurması gerekir. Bu denge, fikir birliği içinde kuruluşlar ve çalışanlar arasında karşılıklı anlayışla sağlanmalıdır (Lin vd., 2010: 358-362). Kurumsal vatandaşlık, bir örgütün paydaşlarla ve doğal çevre üzerindeki ilişkilerini operasyonel hale getirirken geliştirdiği stratejiler ve işletme uygulamalarında kendini gösterir. Tüm bu ilişkilerde ve işletmelerin paydaşlarına davranış biçimlerinde bir dereceye kadar kurumsal vatandaşlık mevcuttur 
(Waddock, 2004: 8-11). Kurumsal vatandaşlık üzerine yapılan çalışmalar ile ilgili bilim insanlarının görüşleri özetlenerek Tablo 2' de verilmeye çalışılmıștır.

Tablo 2. Kurumsal Vatandașlık ile İlgili Bilim İnsanlarının Görüșleri

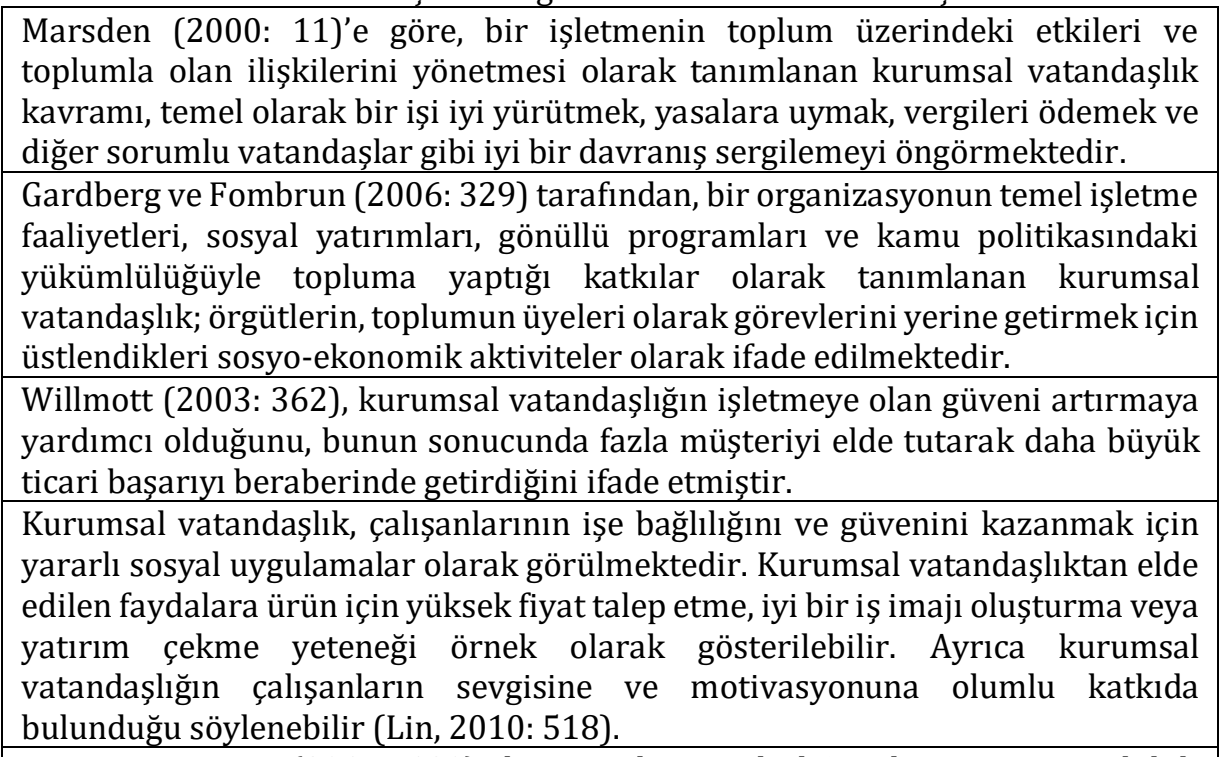
Evans ve Davis, (2014: 130), kurumsal vatandașlı̆ın dört tür sorumluluk içerdiğini belirtmiștir. Bunlar; kar ve ișletme verimliliği için mali sorumluluk, kanunlara ve tüm düzenlemelere uymak olan yasal sorumluluk, tedarikçilere ve müșterilere adil ve şeffaf davranmayı gerektiren etik sorumluluk ve isteğe bağlı olarak gerçekleștirilen hayırsever sorumluluklardır.

Fombrun vd. (2000: 85)'ne göre, kurumsal vatandaşlığın kurum ve yerel topluluk arasındaki sosyal bağları güçlendirerek, kurumun yerel toplulukların sosyal dokusuna entegre olmasına yardımcı olabileceği belirtilmiștir.

Marsden ve Andriof (1998: 329) iyi kurumsal bir vatandaşlığı, bir kuruluşun toplum üzerindeki olumsuz etkilerini ve ilişkilerini en aza indirerek, olumlu olanları en üst düzeye çıkaracak şekilde anlama ve yönetme şekli olarak ifade etmiștir.

Waddock (2004: 8-11), bir örgütün paydaşları ve doğal çevresi ile ilişkilerini operasyonel hale getirirken geliştirdiği stratejiler ve işletme uygulamalarını kurumsal vatandaşlık olarak tanımlamıștır.

Swaen ve Maignan (2001: 16), kurumsal vatandaşlı̆ı̆ı öncüllerini paydaşların baskıları, şirketin pazar ve insancıl yönelimleri, yöneticilerin desteği ve liderliği, yöneticilerin değerleri ve idealleri, iç ve dış üst düzey yöneticilerin tutumları olarak ifade etmiștir. Kurumsal vatandaşlığın sonuçları olarak ise; ekonomik performans, itibar, çalışanların iş memnuniyeti, örgütsel bağlılık, verimlilik ve potansiyel işveren olarak çekicilik, tüketicilerin sadakati, tüketiciler tarafından firma ve ürünlerinin değerlendirilmesi ve șirketin desteklenmesi olarak belirtmiștir.

\section{KURUMSAL SOSYAL SORUMLULUK}

Son yıllarda bireyler sürdürülebilir kalkınma konusunda endişeli olduklarından talep ettikleri ürünlerde giderek daha fazla fayda aramaktadır. Bu fayda, sadece kaliteli ve ucuz fiyatlı ürün ve hizmet değil, aynı zamanda sosyal ve 
çevreye saygılı ürün ve hizmetleri de kapsamaktadır. Kapsamlı bir kurumsal sosyal sorumluluk sosyal, çevresel ve ekonomik boyutları kapsayan çok çeşitli politikaların ve uzlaşmaların kuruluşlar tarafından benimsenmesini ve bunların tüm kuruluşun etki alanı üzerinde uygulanacak süreçlere dönüştürülmesini gerektirmektedir (Leon ve Juan, 2014: 82). Bugün büyük çaptaki uluslararası işletmelerin kurumsal sosyal sorumluluk politikasına sahip olmaması neredeyse düșünülemez. Yüksek çalıșma standartlarının sağlanması, çevresel sürdürülebilirliğin teşvik edilmesi veya yerel toplulukların desteklenmesi küresel işletmelerin gündemlerinin üst sıralarında yer almaktadır (Bohdanowicz ve Zientara, 2009: 155).

Başlangıcı 1960 ve daha öncesine dayanan kurumsal sosyal sorumluluk kavramı, insan çıkarlarının kurumsal çıkarların üzerinde olduğu kabul edilen ahlaki fikirler üzerine kurulmuştur. Kurumsal sosyal sorumluluk, kurumsal güç dengesizliğinin, yani çevresel bozulmanın ve zehirlenmenin, sağlıksız ve hatta ölümcül tüketici ürünlerinin ve insanlık dışı iş yerlerinin yıkıcı sonuçlarına karşı koymak için geliştirilmiştir. Ancak kurumsal sosyal sorumluluğun ilk savunucuları arasında onun ahlaki özünün doğası konusunda farklı görüşler vardır. 0 dönemin pek çok entelektüeli tüm insanlara, tüm haklara, tüm meselelere saygılı olmayı savunmuşlardır. Ancak bu onları çeşitli kültürlerin "iyi" ve "kötü" özelliklerini ayırt etmede zorluklarla karșı karșıya getirmiștir. Birçok kiși için kurumsal sosyal sorumluluğu kibirli, tek taraflı ve kısa süre önce benzeri görülmemiș bir zenginlik ve teknolojik ilerlemeler üreten iş dünyasından çok talepkâr bir yaklaşım olarak görünüyordu. Aynı zamanda, bazı kişiler için ise kurumsal sosyal sorumluluk, çok tembel, çok geniş, çok belirsiz ve halkla ilişkiler aracından yetersiz olarak eleştiriliyordu. Bu eleştirilere rağmen kurumsal sosyal sorumluluk, iș dünyasında öne çıkma ve bilinçlendirme amaçlarına hizmet etmiş ve çevresiyle iş kompleksine dikkat çekerek işletme eğitiminde geniş bir paydaş bakış açısını benimseyerek uygun bir kabul sağlamıştır (Logsdon ve Wood, 2002: 157).

İşletmelerin, sivil toplum kuruluşları ile stratejik bir ortaklık oluşturması kurumsal sosyal sorumluluğun gelişmesi ve demokratik bir toplumun oluşması için önem arz etmektedir (Bük ve Akboğa, 2020: 832). İşletmelerin kurumsal sosyal sorumlukları; çalışanlarına yönelik sorumlulukları, çevreye yönelik sorumlulukları, yasal sorumlulukları ve bireylere yönelik sorumluluklardan olușmaktadır (Ata ve Ataman, 2020: 262). Kurumsal sosyal sorumluluk kavramı kullanıldığında, son derece eksik bir tanım olan, işletmenin temel hedefine ulaşırken çevre ve doğayı koruyarak üretimde bulunması akla gelmektedir. Hâlbuki bir işletmenin bu sorumluluklarının yanı sıra doğrudan veya dolaylı olarak içerisinde bulunduğu tüm paydaşlarına karşı sorumluluğu vardır. İşletmeler, kurum içi ve kurum dişı olarak tanımlanan bu sorumluluklarını yerine getirirken bir denge kurmak zorundadır. İşletmeler kurumsal sosyal sorumluluk faaliyetlerinden kurum imajı ve kurum itibarı gibi ciddi kazanımlar elde ettiğinden, son yıllarda kurumsal sosyal sorumluluğa daha fazla önem vermeye bașlamıșlardır. Bunların sonucunda değișen kurumsal sosyal sorumluluk anlayıșına bağlı olarak günümüzde sosyal denetim, etik denetim, sosyal raporlama ve kurumsal vatandaşlık gibi kurumsal sosyal sorumluluk kavramıla birlikte anılan kavramlar ortaya çıkmaya başlamıştır (Akatan, 2007: 9-13). İşletmelerin verimli ve karlı olmayı gerektiren ekonomik; kanunlara uymayı gerektiren hukuki; toplumun norm ve beklentilerine uymasını sağlayan etik ve toplum sorunlarını çözmek için gönüllü 
olmak üzere dört temel kurumsal sosyal sorumluluğu vardır. Kurumsal sosyal sorumluluk bunlardan son ikisini doğrudan, diğer ikisini de dolaylı olarak içermektedir (Argüden, 2007: 26).

Kurumsal sosyal sorumluluk; reaktif, savunmacı, uyumlu ve proaktif olmak üzere dört kategoriye ayrılmıştır. Reaktif organizasyonlar sosyal sorumlulukları reddederken ve toplumun standartlarının gerektirdiğinden daha azını yaparken, proaktif işletmeler gelecekteki sorumlulukları öngörür ve asgari gerekliliklerin ötesinde hareket eder (Malgnan vd., 1999: 456).

Kurumsal sosyal sorumluluk herkes için farklı bir şey ifade etmektedir. Bazılarına yasal sorumluluk veya sorumluluk fikrini akla getirirken, bazıları için etik anlamda sosyal sorumluk davranışı anlamına gelmektedir. Kurumsal sosyal sorumluluk, kaynakların sadece kişi ve firmaların dar sınırlandırılmış çıkarları için değil, geniş sosyal amaçlar için kullanıldığını görme istekliliğidir. Bu çerçevede ekonomik olduğu kadar sosyal bir kurum olan firmalar, hükümetler ile işbirliğini en iyi şekilde yapmalıdır. Bir işletme, işe bağlı kalarak topluma en iyi hizmet eden, kar eden, mal ve hizmet üreten ekonomik bir kurumdur. İşletmeler, tam ürün bilgisine sahip olmalı, aldatıcı ürün yapmamalı, fiyatlandırma politikalarında istismarcı olmamalı, güvenli olmayan ürünleri pazarlamamalı ve aldatıcı uygulamalarda bulunmamalıdır. Çevreye zarar vermemeli, bireylere eşit davranmalı, onlara eşit düzeyde fırsatlar vermeli, özgür ve katılımcı bir ortam yaratmalı, kamu tüzüğüne bağlı olmalı, toplumsal talepleri karşılamalı ve sosyal adaleti teşvik etmek için aktif olarak çalışmalıdır (Zenisek 1979: 366). Günümüzde farkındalık düzeylerinin yükselmesi ile kaliteli ve ucuz ürün ile birlikte paydaşlarına karşı sosyal sorumluluklarını yerine getiren işletmelere itibar edilmektedir. $\mathrm{Bu}$ gelişmeler doğrultusunda işletmeler, kurumsal sosyal sorumluluğu iş süreçlerinin stratejik bir parçası olarak görmektedir. Birçok işletme paydaşlarının sosyal sorumluluk kapsamında beklentilerini karışlayarak marka itibarını ve pazar payını artırmakta, finansal kaynaklara daha kolay ulaşabilmektedir. Kurumsal sosyal sorumluluk ilkeleri doğrultusunda, toplumun faydasına olan kanun ve kurallara daha uyumlu davranan işletmeler, daha iyi üretim ve inovasyona sahip olacağından rakiplerine göre daha avantajlı konuma gelmektedir (Gülmez ve İnan, 2020: 41).

Modern anlamda kurumsal sosyal sorumluluk yaklaşımı, işletmelerin amaçlarına ulaşmak ve varlığını sürdürmek için sunduğu ürün ve hizmetten kar elde etmenin yanı sıra toplumun ve bireylerin refahını ve yaşam kalitesini arttırmak olarak da ifade edilmektedir. Bu yaklaşıma göre işletmeler etkileşim içerisinde bulunduğu iç ve dış paydaşlarının beklentilerini karşılayarak, sorunlarına en uygun çözümler üretmeyi amaçlayan bir yaklaşım içerisinde olmalıdır. Kurumsal sosyal sorumluluk tüketicilere, yatırımcılara, işletmelere ve sivil toplum örgütlerine fayda sağlayan faaliyetlerdir (Şen, 2020: 5). Kurumsal sosyal sorumluluk üzerine yapılan çalışmalar ile ilgili bilim insanlarının görüşleri özetlenerek Tablo 3' de verilmeye çalışılmıștır. 
Tablo 3. Kurumsal Sosyal Sorumluluk ile İlgili Bilim İnsanlarının Görüşleri

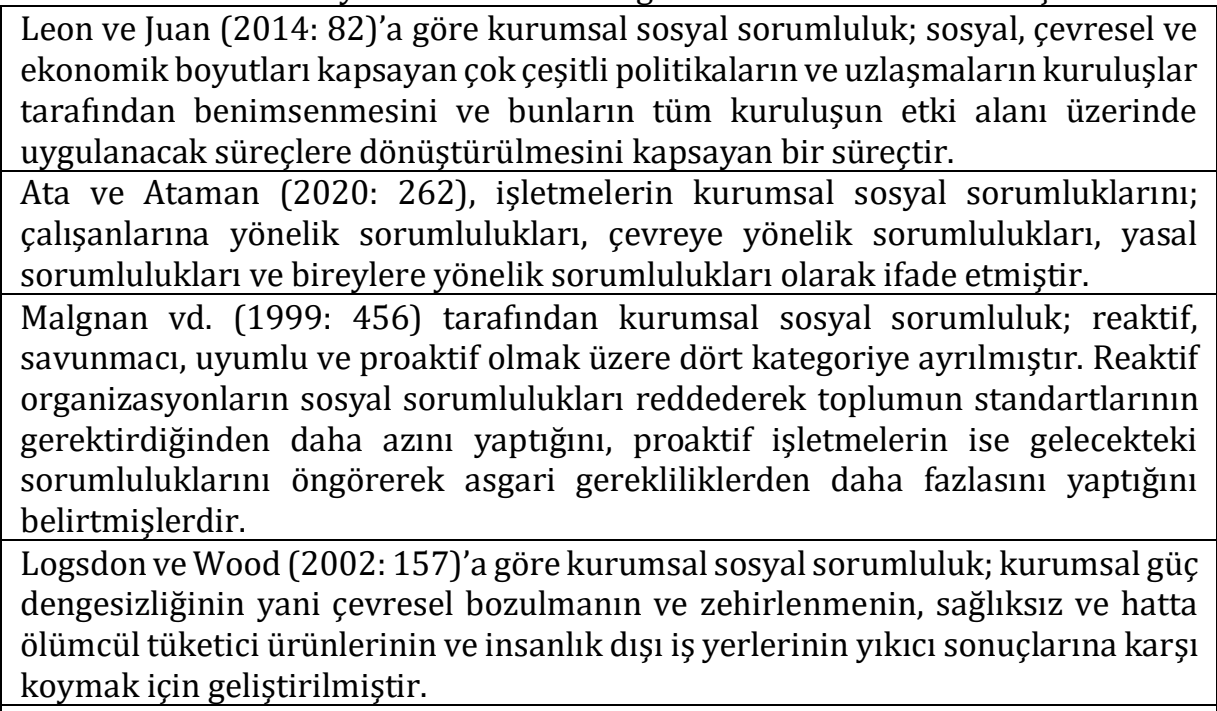
Zenisek (1979: 366)'e göre kurumsal sosyal sorumluluk; bazılarına yasal sorumluluk veya sorumluluk fikrini akla getirirken, bazıları için etik anlamda sosyal sorumluk davranışı anlamına gelmektedir. Çevreye zarar vermemek, bireylere eșit davranmak, onlara eşit düzeyde firsatlar vermek, özgür ve katılımcı bir ortam yaratmak, kamu tüzügüne bağlı olmak, toplumsal talepleri karşılamak ve sosyal adaleti teşvik etmek için aktif olarak çalışmak kurumsal sosyal sorumluluk davranışları olarak görülmüsstür.

Carroll (1979: 500)'a göre kurumların topluma karşı yükümlülüklerini karşlayacak sosyal sorumluluklarının, ekonomik, yasal, etik ve isteğe bağlı faaliyetleri içermesi gerekmektedir. Bu rollerin tamamen gönüllülük esasına dayandığını ve bunları üstlenmenin ișletmeler için zorunlu kılınmadığı, yasaların gerektirmediği ve hatta bunların genellikle işletmelerden etik anlamda beklenilmeyen sosyal rollere girme arzusu tarafından belirlendiğini ifade etmiștir.

Robin ve Reidenbach (1987: 45)'e göre kurumsal sosyal sorumluluk; toplumun refahı üzerindeki kurumsal etkiyle ilgili genel kabul görmüş ilişkiler, yükümlülükler ve görevler kümesini ifade etmektedir.

Kurumların topluma karşı yükümlülüklerini karşlayacak sosyal sorumluluğun, ekonomik, yasal, etik ve isteğe bağlı faaliyetleri içermesi gerekir. Bu dört temel beklenti, işletmelerin sosyal sorumluluklarını daha kapsamlı bir şekilde kategorize eden bir sosyal sorumluluk görüşünü yansıttr. Bu dört kategori birbirini dışlamadığı gibi bir tarafta ekonomik kaygılar, diğer tarafta sosyal kaygılar içeren bir çatışmayı da amaçlamazlar. Bu tür sorumluluklar, ticari kuruluşlar için her zaman eşzamanlı olarak var olmuş olsa da, işletmelerin tarihinde ekonomik ve yasal yönlere erken bir vurgu yapıldığı, daha sonra etik ve isteğe bağlı yönlerin geldiği görülmektedir. İşletmeler ekonomik bir birim olduğundan işletmenin ilk ve en önemli sosyal sorumluluğu doğası gereği ekonomiktir. İşletmelerin her şeyden önce toplumun istediği mal ve hizmetleri üretme ve bunları kârla satma sorumluluğu vardır. Diğer tüm sorumluluklar bu temel varsayıma dayanmaktadır. Toplum, işletmelere üretken rolü üstlenmeye izin verirken, aynı zamanda iş dünyasından uyması istenilen temel kuralları, yasaları ve düzenlemeleri de 
belirlemiştir. Toplum, bir işletmenin ekonomik misyonunu yasalar çerçevesinde yerine getirmesini ister. Ekonomik ve yasal sorumluluklar etik normları içermesine rağmen, hukuken belirtilmemiş olsa da toplum üyeleri tarafından iş dünyasından mutlaka yapılması istenilen davranışlar ve faaliyetler vardır. Etik sorumluluklar olarak ifade edilen bu davranışların tam olarak iyi tanımlanmasında sorunlar yaşandığından işletmelerin başa çıkmada en çok zorluk yaşadığı alandır. Son yıllarda, etik sorumluluklar açıkça vurgulansa da neyin etik olup, neyin olmadığına dair tartışmalar devam etmektedir. İşletmelerin isteğine bağlı olarak toplumun kendilerinden beklentileri ile oluşan sorumluluklar da vardır. Toplumun, yapılması için net bir mesajının olmadığı bu beklentiler sorumluluktan öte işin takdirine bağlıdır. Ancak işletmelerin şimdiye kadar açıklananların ötesinde sosyal rolleri üstlenmeleri için toplumsal beklentiler mevcuttur. Bu roller tamamen gönüllülük esasına dayanır ve bunları üstlenme kararı işletmenin zorunlu kılınmadığı, yasaların gerektirmediği ve hatta genellikle işletmelerden etik anlamda beklenmeyen sosyal rollere girme arzusu tarafından belirlenir. Örneğin; sosyal kurumlara hayırsever katkılarda bulunmak, uyuşturucu bağımlıları için programlar yapmak veya işsizleri eğitmek vb. olabilir (Carroll, 1979: 500).

$\mathrm{Bu}$ yaklaşımlar doğrultusunda kurumsal sosyal sorumluluk, işletmelerin insani ve çevresel faktörleri göz önünde tutarak faaliyetlerini bunlara zarar vermeyecek, hatta bunları destekleyecek şekilde düzenlemesi olarak ifade edilebilir. Yani kurumların yürütmüş olduğu tüm faaliyetlerinde, kullandığı girdilerde ve ürettiği çıktılarda tüm paydaşlarına karşı sorumluluklarına göre hareket etmesidir.

\section{KURUMSAL VATANDAŞLIK - ÖRGÜTSEL VATANDAŞLIK}

Örgütsel vatandaşlık, çalışanların herhangi bir karşılık beklemeksizin gönüllü olarak arkadaşlarına ve kurumuna karşı olumlu tutum ve davranışlar sergilemesi (Sökmen ve Boylu, 2011: 147) olarak ifade edilirken; kurumsal vatandaşlık, bir işletmenin toplum üzerindeki etkilerini ve toplumla olan ilişkilerini yönetmesinde üstlendikleri sosyo-ekonomik aktiviteleri ifade etmektedir (Gardberg ve Fombrun, 2006: 329; Marsden, 2000: 11). Kurumsal vatandaşlıkta esas düşünce işletmelerin bir vatandaş gibi sorumluluklar taşımasıdır. Bu sorumluluklar, kurum paydaşlarının farkına vararak onlar ile gönüllü birliktelikler temelinde kuruma değer katacak şekilde paydaşlarının refahına ve çevresine duyarlı hareket tarzlarıdır. Kurumların vatandaşı olduğu topluma karşı etik ve sosyal görevlerinin olduğu bir gerçektir. Kurumsal vatandaşlık, işletmelerin paydaşları üzerinde güven duygusu oluşturarak uzun vadede varlıklarını sürdürmelerine katkı sağlamaktadır (Ustakara, 2016: 13). Kurumsal vatandaşlık bu şekilde ifade edilirken, örgütsel vatandaşlıkta ise esas düşünce bireyin çalıştı̆̆ı kurum içerisinde bir vatandaş gibi sorumluluklar taşımasıdır. Örgütsel vatandaşlık davranışları isteğe bağlı, resmi ödül sistemi tarafından doğrudan veya açık bir şekilde ödüllendirilmeyen ve bir bütün olarak örgütün etkili işleyişini destekleyen bireysel davranışlar olarak tanımlanır. İsteğe bağlı olarak davranışın, rolün veya iş tanımının, yani kişinin kuruluşla olan iş sözleşmesinde yapmak zorunda olmadığı, ihmal edilmesi durumunda cezalandırılabilir olmayan kişisel bir seçim davranışıdır (Podsakoff vd., 2000: 513). Kurumsal vatandaşlık çalışanların bağllığını, sosyal kimliğini ve adalet algısını teşvik ettiğinden kurumsal vatandaşlığın bireylerin örgütsel vatandaşlık davranışlarının gelişmesine olumlu yönde etkisinin olması muhtemeldir (Swaen ve Maignan, 2001: 24). 
Örgütsel vatandaşlık, güçlük yaşayan kişilere yardım etmeyi öngören fedakârlık, idealden daha azıyla yetinme olan vicdanlılık, herhangi bir davranıșta bulunmadan önce nezaket tabanlı bilgilendirme, kendini sorumlu görerek görüşünü bildirme olan sivil erdem ve olumsuz davranışlardan kaçınan centilmenlik yönleri olan bir davranış şeklidir (Podsakoff vd., 1990: 115). Kurumsal vatandaşlık ise, işletmelerin verimliliği ve çalışanların iş sahibi olmasını sağlayan ekonomik, faaliyetlerinde düzenlemelere uymak olan yasal, şeffaflık ilkeli beklentileri kapsayan etik ve gönüllülük esaslı olan hayırsever faaliyetlerde bulunmayı öngören davranışlardan oluşmaktadır (Evans ve Davis, 2014: 130). Örgütsel vatandaşlık ve kurumsal vatandaşlık birtakım ortak temellere sahip olsalar da bu iki yapının bir birinden farklı yapılar olduğuna hiç șüphe yoktur. Vatandaşlık, kurum içinde veya dışında gerçekleştirilebilecek bir dizi davranışı tanımlar. Örgütsel vatandaşlık ve kurumsal vatandaşlık farklı oyuncuları (çalışanlar/organizasyon) içerir ve farklı kuruluşlara (organizasyon/paydaşlar) fayda sağlar. Örgütsel vatandaşlar kendi organizasyonlarından sorumlu oyuncularken, kurumsal vatandaşlar toplumdan sorumlu oyunculardır (Swaen ve Maignan, 2001: 22). Burada da ifade edildiği gibi örgütsel vatandaşlık davranışları birey temelli olup, bireylerin kurumuna ve beraber çalıştığı kişilere karşı davranışlarını kapsamaktadır. Kurumsal vatandaşlık ise kurum temelli olup, kurumun içinde bulunduğu topluma karşı davranışlarını kapsarken, bu davranışlarında göz önünde tutacağı etik ve yasal düzenlemelere uymayı öngörmektedir.

Örgütsel vatandaşlık ve kurumsal vatandaşlık davranış türleri birbirinden farklı eylemler için kullanılan terimlerdir. Ancak yapılan bazı çalışmalarda örgütsel vatandaşlık ve kurumsal vatandaşlık davranışlarının birbirinin yerine kullanıldığı ve örgütsel vatandaşlık davranışlarının kurumsal vatandaşlık davranışı olarak ifade edildiği görülmektedir. Yapılan bir araştırmada, çalışanların zorunlu olmaksızın kendi istekleri ile yaptıkları, beraber çalıştığı kişileri destekleyen kurumun faydasına olan kapsayıcı ve yapıcı davranışlar olan örgütsel vatandaşlık davranışları kurumsal vatandaşlık olarak ifade edilmiştir (İzci ve Sevinç, 2015: 53). Ancak, kavramların birbirlerinin yerine sehven kullanıldığı çalışmalara bakıldığında, genellikle alan araştırması özel sektörde değil kamu sektöründe yapılmış ise kamudaki örgütlenmeler firma, işletme veya örgüt olarak isimlendirilmeyip daha çok kurum olarak ifade edildiğinden vatandaşllk konusu da örgütsel vatandaşlık değil kurumsal vatandaşlık olarak adlandırılmaktadır. Oysa çalışmalara bakıldığında esas anlamda bireyin kurumuna karşı vatandaşlığını ifade eden örgütsel vatandaşlık konusunu irdelemekte olduğu görülmektedir. Dolayısıyla, Türkçede zaman zaman örgüt ve kurum sözcüklerinin birbirinin yerine kullanılmasına bağlı olarak araştırmalarda kurumsal vatandaşlık ile örgütsel vatandaşlık kavramlarının eş anlamlı olarak kullanılma ihtimali yüksektir. Bu tür ifadeler örgütsel vatandaşlık ve kurumsal vatandaşlık kavramalarında kavram kargaşasının ortaya çıkmasına neden olabilmektedir. Ancak bu kavramları doğru bir şekilde ifade eden birçok araştırmalar da vardır. Sarıkaya ve Kara (2007: 228), Tunçel (2011: 79), Summak (2016: 159), Kruggel vd. (2020: 15), Rendtorff (2020: 47), Bulduklu (2014: 1), Özdemir ve Dinçer (2013: 319) tarafından yapılan araştırmalarda kurumsal vatandaşlı̆ı̆n ekonomik, yasal, etik ve sosyal görevler olarak anlaşılması gerektiği önerilmektedir. Son yıllarda ülkemizde ve uluslararası alanlarda yapılan bu araştırmalar, örgütsel vatandaşlık ve kurumsal vatandaşlığın 
farklı anlamlar taşıyan davranış türleri olduğunu göstermektedir. Burada belki de, örgütsel vatandaşlık kavramı yerine "örgüt içi vatandaşlık/kurum içi vatandaşlık", kurumsal vatandaşlık kavramı yerine de "kurumun vatandaşlığı/örgütün vatandaşlığı" gibi kavramların kullanılması söz konusu kavram karmaşasını ortadan kaldırabilirdi. Şayet kavramlar böyle kullanılsaydı, örneğin kamu kurumunda yapılan ve bireyin örgüt içinde gösterdiği vatandaşlık davranışlarını inceleme konusu yapan yani örgütsel vatandaşlığı ele alan çalışmalarda, örgüt içi vatandaşlık kavramı kurum içi vatandaşlık olarak dönüştürüldüğünde dahi kavramsal kargaşa yaşanmamış olurdu.

\section{KURUMSAL VATANDAŞLIK - KURUMSAL SOSYAL SORUMLULUK}

Akademik literatür incelediğinde benzer veya aynı anlamları ifade eden bir dizi farklı terim ve tanım görülebilir. Bu uygulama ve akademik akımlar birçok açıdan birbirine benzerlikler göstermektedir. Bazı ülkelerdeki araştırmacılar kurumsal sosyal sorumluluk terimini daha yaygın olarak kullanırken, başka ülkelerdeki araştırmacılar kurumsal vatandaşlık kullanımını tercih etmektedir (Valor, 2005: 192). Kurumsal sosyal sorumlulukla benzerlikler gösteren kurumsal vatandaşlık, işletmelerin paydaşlarına karşı üstlendikleri ekonomik, yasal, etik ve isteğe bağlı sorumlulukları ne düzeyde yerine getirdiği ilkeleri üzerine kurulmuştur (Özdemir ve Dinçer, 2013: 322).

İș dünyasının toplumdaki rolünü kavramsallaştıran yönetim literatüründeki iş silsilesinin bir uzantısı olan kurumsal vatandaşlık, kurumsal sosyal sorumluluk kavramının hâkimiyetinde olup son yıllarda kurumsal vatandaşlık, kurumsal sosyal sorumluluğa dâhil edilmiștir. Bununla birlikte işin sosyal rolünü çevreleyen tartışmaya kurumsal vatandaşlık terimi eklenmesine rağmen, yönetim literatüründe net, spesifik ve geniş çapta kabul gören bir kurumsal vatandaşlık tanımı henüz geliştirilememiștir. Genişletilmiş̧ kavramsallaştırmalarda kurumsal vatandaşlık daha teorik temellidir ve bazı işletmelerin oynadığı belirli bir rolü daha açıklayıcıdır (Matten ve Crane, 2005: 167). Kurumsal sosyal sorumluluğun, işletmelerin kurumsal bir vatandaş olarak topluma katılabilmesi ve katkıda bulunabilmesi için sürdürülebilir kalkınma sürecine katkıda bulunmada işletmenin stratejik rolünü operasyonel hale getirmenin anahtarı olduğu ifade edilmektedir. Bu durum, işletmeler açısından paydaşlar ile hem iç değişim hem de uyum ilişkileri açısından dış proaktivite ihtiyacını ifade eder (Warhurst 2001: 61). Kurumsal sosyal sorumluluk kavramı daha kolay kabul gören bir kurumsal vatandaşlık kavramı olarak görülmeye başlanmıştır. İş dünyası toplum temelli faaliyetlerini ifade ederken, bir işletmenin genel kurumsal sosyal sorumluluğunun parçası olan sivil ve hayırsever programları tanımlamak için daha iyi bir terim olan kurumsal vatandaşlığı yaygın olarak kullanmaktadır. Ancak yine de kurumsal vatandaşlık kavramı, kurumsal sosyal sorumluluğun yerine tam olarak ikame etme açısından yetersiz kalmaktadır (Logsdon ve Wood, 2002: 157). Bu yüzden kurumsal sosyal sorumluluk ile ilgili yapılan tartışmalarda, kurumsal vatandaşlı terimi bazen çok özel bir alt durum olan kurumsal gönüllülüğ̈ belirtmek için kullanılmaktadır (Pies vd., 2009: 396).

İşletmeleri sorumlu davranmaya zorlama girişiminde başarısız olan kurumsal sosyal sorumluluk, işletmeleri iyi kurumsal vatandaşlar gibi davranmaya teşvik etmeyi amaçlayan daha uzlaşmacı bir yaklaşıma dönüştürülmüştür. Kurumsal vatandaşlık için öngörülen rol, Birleşmiş Milletler Küresel İlkeler 
Sözleşmesi'nde gösterildiği gibi etkili bir kurumsal sosyal sorumluluk rejimi için gerekli normların rızaya dayalı yöntemlerle oluşturulmasıdır. Kurumsal vatandaşlık, kabul edilen normların oluşturulmasında ișletmelerin, demokratik kurumların ve sivil toplum kuruluşlarının esnek ve rızaya dayalı programları kullanması sayesinde bu durumu iyileştirme potansiyeline sahip görünmektedir. Kurumsal sosyal sorumluluğun yerini kurumsal vatandaşlık kavramının aldığı varsayımı oluşsa da, kurumsal vatandaşlık kurumsal sosyal sorumluluğun ikamesi olarak değil, onun tamamlayıcısı olarak görülmelidir. Kurumsal sosyal sorumluluk ve kurumsal vatandaşlık alternatifler olarak değil ulusal, uluslararası ve küresel ölçekte önemli ve anlamlı kurumsal faaliyet reformunu gerçekleştirmek için kombinasyon halinde kullanılabilecek tamamlayıcı kavramlar olarak görülmelidir (Whitehouse, 2003: 300).

Kurumsal vatandaşlık, iş organizasyonu ve çeşitli topluluk paydaşları arasında genellikle daha geniş olan kurumsal sosyal sorumluluk kavramının bir alt kümesini ifade eden bir kavram olarak görülmektedir. Avrupa'da, kurumsal vatandaşlık kavramı hala daha yerleşik kurumsal sosyal sorumluluk ideolojileriyle rekabet halindedir. Bu durum kurumsal vatandaşlık ile paydaşlar arasında sorunlu bir ilişkinin yürütülmesi anlamına gelmektedir (Mohan, 2001: 116). Kurumsal vatandaşlığın teorik tanımı yönetim çalışmalarında kurumsal sosyal performans ve paydaş yönetimi konusunda yapılan araştırmalarda da ifade edilmiştir. Kapsamı son derce geniş olan kurumsal sosyal performans, ahlaki, yönetimsel ve sosyolojik konuları kapsarken; kurumsal vatandaşlık, yalnızca sosyal talepleri karşılamak için işletmeler tarafından üstlenilen faaliyetleri içermektedir. $\mathrm{Bu}$ sınıflandırmaya dayanarak, iyi kurumsal vatandaşların ekonomik, yasal, etik ve isteğe bağlı vatandaşlık ile sosyal sorumlulukları üstlenmeleri beklenebilir (Malgnan vd., 1999: 456).

Günümüzde işletmelerin faaliyet gösterdiği topluluklarla ve yaptıklarından etkilenenlerle ilişki kurmasının daha önemli olduğu kabul edilmektedir. Bu faaliyetler genel olarak kurumsal sosyal sorumluluk olarak geniş bir şekilde ifade edilmektedir. Bu çeşitli sorumlulukları tek bir terim olan kurumsal sosyal sorumluluk olarak tanımlamak olayı basitleştirdiğinden büyük ölçüde kafa karışıklı̆̆ına da neden olmaktadır. İşletmelerin topluma dahil olmak için yaptıkları işin adil bir şekilde tanınması, takdir edilmesi ve şirketlerin kendilerini farklı işletmelerin performanslarıyla daha iyi kıyaslayabilmeleri için farklı kurumsal faaliyet türleri arasında ayrım yapılması gerekir. Bu kapsamda iş dünyası için işletmelerin yalnızca paydaşlarıyla değil, hükümetler ve sivil toplumla birlikte paydaş olmaları gerektiği inancını ifade eden küresel kurumsal vatandaşlık olarak tanımlanan yeni bir tanım kabul edilmelidir. Küresel kurumsal vatandaşlık, dünya için önemli konulara makro düzeyde katılım anlamına gelir. Küresel kurumsal vatandaşlık, bir işletmenin dünyanın geleceği üzerinde etkisi olan iklim değişikliği, aşırı fakirlik, eğitim, su kıtlığı, bulaşıcı hastalıklar ve terörizm gibi sorunları ele almadaki rolünü ifade eder. Çözümlere yerel olarak odaklanılmış olunsa bile, bu sorunların her birinin kapsamı küreseldir (Schwab, 2008: 107-114). 


\section{SONUÇ}

Örgütsel vatandaşlık ile kurumsal vatandaşlık işletme biliminde farklı anlamları olan davranışlardır. Örgütsel vatandaşlık birey temelli olup, bireylerin kurumuna ve beraber çalıştığı kişilere karşı fedakârlık (özgecilik), vicdanlılık, nezaket tabanlı bilgilendirme, sivil erdem ve centilmenlik gibi unsurları içeren davranışlarından oluşmaktadır. Kurumsal vatandaşlık ise bir kurumun içinde bulunduğu topluma karşı ekonomik, yasal, etik ve hayırsever unsurları taşıyan, ancak ağırlıklı olarak gönüllülügün ön planda tutulduğu davranışları ve eylemleri ifade etmektedir. Örgütsel vatandaşlık ve kurumsal vatandaşlık bazı özellik ve eylem bakımından ortak benzerlikler taşısa da, örgütsel vatandaşlıkta ana unsur olan bireylerin hedefi kurum ve beraber çalıştığı kişilerken, kurumsal vatandaşlıkta ana unsur olan işletmelerin hedefi içinde bulunduğu toplumdur.

Kurumsal sosyal sorumluluk bir anlamda işletimlerin içinde bulunduğu çevrenin tüm değerlerini dikkate alarak onlara zarar vermeden, paydaşlarına karşı yükümlülüklerini ve yapmak zorunda olduğu davranışlarını ifade etmektedir. İşletmelerin kurumsal sosyal sorumluluğu, karlılık için ekonomik sorumluluğunu; toplum yasalarına uyma sorumluluğunu, adil olanı yapmak için etik sorumluluğunu ve çeşitli sosyal, eğitim, eğlence veya kültürel amaçlara katkıda bulunmaya yönelik hayırsever sorumluluklarını ifade etmektedir. İşletmeleri sorumlu davranmaya zorlama girişiminde başarısız olan kurumsal sosyal sorumluluğun yerini işletmeleri iyi davranmaya teşvik etmeyi amaçlayan daha uzlaşmacı bir yaklaşım olan kurumsal vatandaşlığa bıraktığı görülmektedir. Kurumsal sosyal sorumluluğun yerini kurumsal vatandaşlık kavramı alsa da, kurumsal vatandaşlık kurumsal sosyal sorumluluğun ikamesi değil, onun tamamlayıcısı olarak görülmelidir. Kurumsal vatandaşlık ve kurumsal sosyal sorumluluk arasındaki ilişki oldukça belirsiz görünmektedir. Bazı bilim adamları farklılıklarını vurgulamakla birlikte, temelde benzer yaklaşımlar olduklarını öne sürmektedir. Kurumsal vatandaşlık, bütünsel bir sorumluluk kavramını temsil eden kurumsal sosyal sorumluluğun bir alt terimi olarak da görülebilir.

Yapılan literatür araştırmasına göre, örgütsel vatandaşlık ile kurumsal vatandaşlığın birbirinden farklı anlamları kapsayan davranışları ifade eden kavramlar olduğu görülmüştür. Ancak kurumsal vatandaşlık ve kurumsal sosyal sorumluluğun birbirlerinden kesin çizgilerle ayrılmadığı, sınırların belirlenmediği ve bu iki kavramın anlam bakımından birbirine yakın davranışları ifade ettiğgi sonucuna ulaşılmıştır. Yapılan bu araştırmada ilk olarak örgütsel vatandaşlık, kurumsal vatandaşlik ve kurumsal sosyal sorumluluk kavramlarında yapılan araştırmalar ve akademisyen görüşleri araştırılmış ve bu konulardaki farklı görüşler ve bakış açıları incelenmeye çalışılmıştır. İkinci olarak örgütsel vatandaşlık, kurumsal vatandaşlık ve kurumsal sosyal sorumluluk kavramaları arasındaki farklılıklar ve benzerlikler karşılaştırılmıştır. Sonuç olarak incelenen literatür bulgularının değerlendirilmesi ile bu kavramlar açıklanmaya çalışılmıştır. 


\section{KAYNAKÇA}

Aktan, Coşkun Can ve Börü, Deniz (2007), Kurumsal Sosyal Sorumluluk, İGİAD Yayınları, İstanbul.

Allison, Barbara - Voss, Richard Steven - Dryer, Sean (2001), "Student Classroom and Career Success: The Role of Organizational Citizenship Behavior", Journal of Education for Business, Volume: 76, Issue: 5, pp. 282-288.

Altıntaş, Füsun Çınar (2006), "Hizmet Çalışanları Olarak Hemşirelerin Örgütsel Vatandaşlık Davranışı Boyutlarını Belirlemeye Yönelik Bir Analiz", Yönetim Bilimleri Dergisi, Cilt: 4, Sayı: 2, ss. 81-90.

Altman, Barbara W. and Cohen, Deborah Vidaver (2000), "A Framework for Understanding Corporate Citizenship", Business and Society Review, Issue: 105, pp. 1-7.

Argüden, Yılmaz (2007), Kurumsal Sosyal Sorumluluk, İGİAD Yayınları, İstanbul.

Ata, Hacer ve Ataman, Göksel (2020), "Kurumsal Sosyal Sorumluluk, Algllanan Dışsal Prestij ve Örgütsel Bağlılı: Sosyal Kimlik Kuramı Çerçevesinde Bir Araştırma", Yönetim Bilimleri Dergisi, Cilt: 18, Sayı: 36, ss. 255-273.

Ateş, Nur Banu - Atabey, Aslı Özen - Şimşek, Mustafa Hakan (2019), “Türkiye’de Yer Alan Lojistik İşletmelerinin Kurumsal Vatandaşlık Çerçevesinde Kurumsal Sosyal Sorumluluk Anlayışlarının Değerlendirilmesi”, II. Uluslararası Kahramanmaraş Yönetim, Ekonomi ve Siyaset Kongresi, ss. 114-126.

Bohdanowicz, Paulina and Zientara, Piotr (2009), “Hotel Companies' Contribution to Improving The Quality of Life of Local Communities and The Well-Being of Their Employees", Tourism and Hospitality Research, Issue: 9, pp. 147-158.

Bolat, Oya İnci - Bolat, Tamer - Aytemiz Seymen, Oya (2009), “Güçlendirici Lider Davranıșları ve Örgütsel Vatandaşlık Davranıșı Arasındaki İlişkinin Sosyal Mübadele Kuramından Hareketle İncelenmesi", Balıkesir Üniversitesi Sosyal Bilimler Enstitüsü Dergisi, Cilt: 12, Sayı: 21, ss. 215239.

Brighman, Baird K. and Moran, John W. (1999), "Building Organizational Citizenship", Management Decision, Volume: 37, Issue: 9, pp. 678-685.

Bulduklu, Yasin (2014), “Kurumsal Vatandaşlığın Kurum İmajı Üzerindeki Etkisi”, Selçuk Üniversitesi Sosyal Bilimler Meslek Yüksekokulu Dergisi, Cilt: 17, Sayı: 7, ss. 1-20.

Bük, Tuğba Bozaykut ve Akboğa, Sema (2020), "Kurumsal Sosyal Sorumluluk Çerçevesinde İşletme-Sivil Toplum Kuruluşları İş Birliklerinin Dinamikleri: Türkiye Örneği”, Ankara Üniversitesi SBF Dergisi, Cilt: 75, Sayı: 3, ss. 813-837.

Carroll, Archie B. (1979), “A Three-Dimensional Conceptual Model of Corporate Social Performance", Academy of Management Review, Volume: 4, Issue: 4, pp. 497-505.

Davenport, Kim (2000), “Corporate Citizenship: A Stakeholder Approach for Defining Corporate Social Performance and Identifying Measures for Assessing It", Business \& Society, Volume: 9, Issue: 2, pp. 210-219.

Dyne, Linn Van - Graham, Jill W. - Dienesch, Richard M. (1994), “Organizational Citizenship Behavior: Construct Redefinition, Measurement, and Validation", Academy of Management Journal, Volume: 37, Issue: 4, pp. 765-802. 
Evans, W. Randy and Davis, Walter (2014), “Corporate Citizenship and The Employee: An Organizational Identification Perspective", Human Performance, Volume: 27, Issue: 2, pp. 129-146.

Fombrun, Charles J. - Gardberg, Naomi A. - Barnett, Michael L (2000), “Opportunity Platforms and Safety Nets: Corporate Citizenship and Reputational Risk", Business and Society Review, Volume: 105, Issue: 1, pp. 85-106.

Gardberg, Naomi A. and Fombrun, Charles J. (2006), "Corporate Citizenship: Creating Intangible Assets Across Institutional Environments", Academy of Management Review, Volume: 31, Issue: 2, pp. 329-346.

Graham, Jill W. (1991), "An Essay on Organizational Citizenship Behavior", Employee Responsibilities and Rights Journal, Volume: 4, Issue: 4, pp. 249270.

Gülmez, Murat ve İnan, Hilal (2020), "Kurumsal Sosyal Sorumluluk İletişimi ve Türkiye'deki Yeri Üzerine Kavramsal Bir Çalıșma", Ç.Ü. Sosyal Bilimler Enstitüsü Dergisi, Cilt: 29, Sayı: 3, ss. 29-48.

İzci, Ferit ve Sevinç, Hüseyin (2015), “Kurumsal Vatandaşlık Davranışı Boyutlarının Araștırılması ve Analizi: Van İl Emniyet Müdürlüğü Örneği", Bartın Üniversitesi İ.İ.B.F. Dergisi, Cilt: 6, Sayı: 12, ss. 53-78.

Jahangir, Nadim - Akbar, Mohammad Muzahid - Haq, Mahmudul (2004), "Organizational Citizenship Behavior: Its Nature and Antecedents", BRAC University Journal, Volume: 1, Issue: 2, pp. 75-85.

Koçel, Tamer (2015), İşletme Yöneticiliği, Beta Yayınları, İstanbul.

Kruggel, Alexander - Tiberius, Victor - Fabro, Manuela (2020), "Corporate Citizenship: Structuring The Research Field", Sustainability, Issue: 12, pp. 1-19.

Lepine, Jeffrey A. - Erez, Amir - Johnson, Diane E. (2002), “The Nature and Dimensionality of Organizational Citizenship Behavior: A Critical Review and Meta-Analysis", Journal of Applied Psychology, Volume: 87, Issue: 1 , pp. 52-65.

Leon, Raul and Juan, Angel A. (2014), "Promoting Corporate Social Responsibility in Logistics Throughout Horizontal Cooperation", Managing Global Transitions International Research Journal, Volume: 12, Issue: 1, pp. 79-93.

Lin, Chieh Peng (2010), "Modeling Corporate Citizenship, Organizational Trust, and Work Engagement Based on Attachment Theory", Journal of Business Ethics, Issue: 94, pp. 517-531.

Lin, Chieh Peng - Lyau, Nyan Myau - Tsai, Yuan Hui - Chen, Wen Yung - Chiu, Chou Kang (2010), "Modeling Corporate Citizenship and Its Relationship with Organizational Citizenship Behaviors", Journal of Business Ethics, Issue: 95 , pp. 357-372.

Logsdon, Jeanne M. and Wood, Donna J. (2002), "Business Citizenship: From Domestic to Global Level of Analysis", Business Ethics Quarterly, Volume: 12, Issue: 2, pp. 155-187.

Malgnan, Isabelle - Ferrel, Oc - Hult, Tomas G. (1999), "Corporate Citizenship: Cultural Antecedents and Business Benefits", Journal of The Academy of Marketing Science, Volume: 27, Issue: 4, pp. 455-469.

Marsden, Chris (2000), "The New Corporate Citizenship of Big Business: Part of The Solution to Sustainability?", Business and Society Review, Volume: 105, Issue: 1, pp. 9-25. 
Marsden, Chris and Andriof, Jorg (1998), "Towards an Understanding of Corporate Citizenship and How to Influence It", Citizenship Studies, Volume: 2, Issue: 2, pp. 329-352.

Matten, Dirk and Crane, Andrew (2005), "Corporate Citizenship: Toward an Extended Theoretical Conceptualization", Academy of Management, Volume: 30, Issue: 1, pp. 166-179.

Mohan, Anupama (2001), “Corporate Citizenship Perspectives from India”, The Journal of Corporate Citizenship, Issue: 2, pp. 107-117.

Moon, Jeremy - Crane, Andrew - Matten, Dirk (2005), “Can Corporations Be Citizens? Corporate Citizenship as a Metaphor for Business Participation in Society", Business Ethics Quarterly, Volume: 15, Issue: 3, pp. 429-453.

Organ, Dennis W. (1990). “The Motivational Basis of Organizational Citizenship Behavior", Research in Organizational Behavior, Issue: 12, pp. 43-72.

Özdemir, Yasemin ve Dinçer, Mustafa Abdül Metin (2013), “Çalışanların Kurumsal Vatandaşlık ile İlgili Algıları: Türkiye'den Ödüllü Bir Örnek", Süleyman Demirel Üniversitesi İktisadi ve İdari Bilimler Fakültesi Dergisi, Cilt: 18, Sayı: 2, ss. 319-337.

Pies, Ingo - Hielscher, Stefan - Beckmann, Markus (2009), "Moral Commitments and The Societal Role of Business: An Ordonomic Approach to Corporate Citizenship", Business Ethics Quarterly, Volume: 19, Issue: 3, pp. 375-401.

Podsakoff, Philip M. - Mackenzie, Scott B. - Moorman, Robert H. - Fetter, Richard (1990), "Transformational Leader Behaviors and Their Effects on Followers' Trust in Leader, Satisfaction and Organizational Citizenship Behaviors", Leadership Quarterly, Volume: 1, Issue: 2, pp. 107-142.

Podsakoff, Philip M. - Mackenzie, Scott B. - Paine, Julie Beth - Bachrach, Daniel G. (2000), “Organizational Citizenship Behaviors: A Critical Review of The Theoretical and Empirical Literature and Suggestions for Future Research", Journal of Management, Volume: 26, Issue: 3, pp. 513-563.

Poyraz, Kemal - Kara, Hakan - Çetin, Seydi Ahmet (2009), "Örgütsel Adalet Algılamalarının Örgütsel Vatandaşılı Davranışlarına Etkisene Yönelik Bir Araştırma", Süleyman Demirel Üniversitesi Sosyal Bilimler Enstitüsü Dergisi, Cilt: 1, Sayı: 9, ss. 71-91.

Rendtorff, Jacob Dahl (2020), “Corporate Citizenship, Stakeholder Management and Sustainable Development Goals in Financial Institutions and Capital Markets", Journal of Capital Markets Studies, Volume: 4, Issue: 1, pp. 47-59.

Robin, Donald P. and Reidenbach, R. Eric (1988), "Social Responsibility, Ethics, and Marketing Strategy: Closing The Gap between Concept and Application", Journal of Marketing, Volume: 51, Issue: 1, pp. 44-58.

Sarıkaya, Muammer ve Kara, Zişan F. (2007), "Sürdürülebilir Kalkınmada İşletmenin Rolü: Kurumsal Vatandaşlık", Yönetim ve Ekonomi, Cilt: 14, Sayl: 2, ss. 221-233.

Schwab, Klaus (2008), "Global Corporate Citizenship: Working with Governments and Civil Society", Foreign Affairs, Volume: 87, Issue: 1, pp. 107-118.

Schnake, Mel E. and Dumler, Michael P. (2003), "Levels of Measurement and Analysis Issues in Organizational Citizenship Behaviour Research", 
Journal of Occupational and Organizational Psychology, Issue: 76, pp. 283301.

Șen, Mesut (2020), “Kurumsal Sosyal Sorumluluk ve Sivil Toplum”, INSAMER, Sayı: 117 , ss. 1-8.

Sezgin, Ferudun (2005), “Örgütsel Vatandaşlık Davranışları: Kavramsal Bir Çözümleme ve Okul Açısından Bazı Çıkarımlar", G.Ü. Gazi Eğitim Fakültesi Dergisi, Cilt: 25, Sayı: 1, ss. 317-339.

Sökmen, Alptekin ve Boylu, Yasin (2011), “Örgütsel Vatandaşlık Davranışı Cinsiyete Göre Farklılık Gösterir mi? Otel İşletmeleri Açısından Bir Değerlendirme", Gaziantep Üniversitesi Sosyal Bilimler Dergisi, Cilt: 10, Sayl: 1, ss. 147-163.

Summak, M. Erhan (2016), "Kurumsal Vatandaşlık Davranışında Halkla İlişsiler Fonksiyonu", Electronic Journal of Vocational Colleges, Cilt: 6, Sayl: 4, ss. 159-168.

Swaen, Valérie and Maignan, Isabelle (2001), "Organizational Citizenship and Corporate Citizenship: Two Constructs, One Research Theme", IAG-LSM Working Papers, http://hdl.handle.net/2078/18283 (10.05.2021).

Ustakara, Fuat (2016), “Bir Halkla İlişkiler Anlayışı Olarak Kurumsal Vatandaşılı", İnönü Üniversitesi İletişim Fakültesi E-Dergisi, Cilt: 1, Sayı: 1, ss. 7-15.

Tunçel, Hakan (2011), “Halkla İlișkiler Perspektifinden Kurumsal Vatandașlık Anlayışına Bir Bakış", Galatasaray Üniversitesi İletişim Dergisi, Sayı: 14, ss. 79-95.

Valor, Carmen (2005), “Corporate Social Responsibility and Corporate Citizenship: Towards Corporate Accountability", Business and Society Review, Volume: 110, Issue: 2, pp. 191-212.

Waddock, A. Sandra (2001), "Integrity and Mindfulness: Foundations of Corporate Citizenship", The Journal of Corporate Citizenship, Issue: 1, pp. 25-37.

Waddock, A. Sandra (2004), “Parallel Universes: Companies, Academics, and The Progress of Corporate Citizenship", Business and Society Review, Volume: 109, Issue: 1, pp. 109, 5-42.

Warhurst, Alyson (2001), "Citizenship and Corporate Social Investment: Drivers of Tri-Sector Partnerships", The Journal of Corporate Citizenship, Issue: 1, pp. 57-73.

Whitehouse, Lisa (2003), "Corporate Social Responsibility, Corporate Citizenship and The Global Compact", Global Social Policy, Volume: 3, Issue: 3, pp. 299-318.

Willmott, Michael (2003), "Citizen Brands: Corporate Citizenship, Trust and Branding", Brand Management, Volume: 10, Issue: 4- 5, pp. 362-369.

Zenisek, J. Thomas (1979), “Corporate Social Responsibility: A Conceptualization Based on Organizational Literature", The Academy of Management Review, Volume: 4, Issue: 3, pp. 359-368. 